\title{
Knowledge and Cooperation Determinants of Innovation Networks:A Mixed-Methods Approach to the Case of Portugal
}

\author{
Hugo Pinto', Maria Teresa de Noronha², Chanda Faustino
}

\begin{abstract}
Systemic perspectives of innovation integrate complex interrelations among enterprise, science and technology, and governance spheres. Innovation networks are crucial within innovation systems and refer to the linkages of a variety of actors with the purpose of innovation. In this article, the determinants of innovation networks are analyzed using a qualitative original database of online information about 623 organizations in Portugal. A binary econometric regression for all types of entities is estimated. The model underlines that actors using external technologies and promoting knowledge are more likely to innovate. In parallel, actors that are involved in managing and supporting entrepreneurship have a smaller probability to do it. Advanced firms and universities are the actors more willing to dynamically innovate. Specific models for firms and universities create a direct comparison between the determinants in both collectives. While promoting knowledge and specific orientation towards innovation is essential for firms it is not relevant for universities. Managing knowledge is the crucial catalyst for the innovation practices in universities. External technological linkages are essential for both types of actors in the creation of innovation networks. The article concludes with policy implications regarding the support of cooperation activities to instigate innovation.
\end{abstract}

Keywords: innovation; innovation networks; innovation system; content analysis; logistic regression.

\footnotetext{
${ }^{1}$ Centre for Social Studies, University of Coimbra and Faculty of Economics, University of Algarve, Campus de Gambelas, Edifício 9, 8005-139 Faro, Portugal, E-mail: hpinto@ces.uc.pt (corresponding author).

${ }^{2}$ Centre for Spatial and Organizational Dynamics and Faculty of Economics, University of Algarve, Portugal

${ }^{3}$ Faculty of Economics, University of Algarve, Campus de Gambelas, Edifício 9, 8005-139 Faro, Portugal
} 


\section{Introduction}

Innovation encompasses a variety of cooperative activities centered in the development of new products and processes and in the increase of competitiveness.As a relational process, innovation involves a diversified group of actors connected by linkages with different degrees of intensity (Fløysand and Jakobsen, 2010). Largely influenced by Nelson and Winter (1982), evolutionary and institutional perspectives of innovation unveil a multifaceted and multi-stakeholder process, characterized by different types of relationships at various levels, such as social, historical, cultural, beyond a narrow economic approach. An essential feature of the knowledge economy is the high degree of innovation, with a very rapid rate at which skills become obsolete and new competencies are developed (Lundvall, 1996). Processes underlying relations linked to innovation, knowledge creation and transfer, relate to interactive learning (Kirat and Lung, 1999). Knowledge is a process itself, not only coming from $R \& D$, since there are many ways of learning, through learning by doing, learning by using, learning by interacting (Lundvall, 1992), the so-called DUI mode of learning. The existence of these evolutionary processes of learning and knowledge are rooted in the territory.

It is essential the attitude of the community toward the promotion of interactive learning, requiring an intention of actors in developing innovation processes and creating synergies (Capello, 1999; Camagni and Capello, 2009). The territory is seen as a relational space (Capello and Nijkamp, 2009), understood as the area for collective action, interpersonal synergies, informal cooperation that empowers and guide actors' behavior (Bramanti and Riggi, 2009). Geographical proximity increases the transfer of tacit knowledge based on face-to-face interactions. The territory becomes the environment where the process of knowledge creation happens, which depends on the competitiveness of regions and existing companies. Geographical proximity is important, but other types of proximity are also relevant (Boschma, 2005). Territorial dynamics of innovation is defined in a systemic way based on a complex environment and how this complexity defines the innovative capacity. Current innovative dynamics is a consequence of evolution, resulting in a sequence of trigger decisions along the pathway. Innovation is therefore not static but dynamic, evolves over time and is path-dependent.
This article assumes implicitly three basic elements that provide a territorial framework to the knowledge creation process: institutions, routines and cumulative knowledge. Institutions are the foundations for the innovation process, creating stability in uncertainty. They refer to habits, rules, traditions of a given society that are embedded within history, culture and the specific developmental trajectories, humanly devised constraints that structure political, economic and social interactions (North, 1991). Routines are created and followed by actors, conferring more predictability to performance. Routines reflect embedded knowledge in organizations, which were created through experience. According to Nelson and Winter (1982), routines shape the behavior of firms in order to enable the ability to have a decision before the problems emerge. Knowledge is cumulative as current knowledge depends on previous accumulated knowledge, defining future developments regarding the direction of innovative enterprises and path dependencies from which territories can hardly escape (McCann and Van Oort, 2009). Relationships that emerge within a given territory define the technological trajectories that may be more or less favorable to innovation (Storper, 1997). In contrast, territories do not have the same record of accomplishment of innovation because these three elements function as stabilizers, are disparate among regions, as well as the interaction within each territory is distinct. From the systemic perspective of Edquist and Hommen (1999), these differences are recognized and considered fundamental to understanding the complexity of innovation in the territory.

The systemic perspective of innovation is particularly relevant as it integrates complex interrelations among enterprise, science and technology, and governance spheres, infrastructure, and institutions (Chaminade and Edquist,2006). Even if initiated with a focus in nation-states performances, the attention to sub-national scales gave prominence to territorialized visions of the innovation dynamics. One example is the term 'regional system of innovation' (RIS) that came into use in the early 1990s, informed by in-depth research on a number of European industrial regions (Uyarra and Flannagan, 20I3). The variety of concepts of 'innovation system' commonly underline the relevance of innovation networks and institutions that are geographically defined, administratively supported, that interact regularly and strongly to enhance the innovative outputs of firms (Cooke and Schienstock, 2000). Innovation is of critical relevance for the evolution of industries where networks are considered one key element (Malerba, 2006). Innovation networks are, in essence, the sets of relationships, ties or links between nodes that represent the existent innovation actors, persons, firms, organizations, interacting in the generation, use and dissemination of new knowledge (Fischer, 2006a), allowing learning and innovation (Lundvall, 1992; Capello, 1999; Asheim, 2007). There are distinct configurations, origins

ISSN: 07 I8-2724. (http://www.jotmi.org)

Journal of Technology Management \& Innovation @ Universidad Alberto Hurtado, Facultad de Economía y Negocios. 
and implications for networks. The concept of network is a major focus of analysis of the economics of innovation but remains unclear the explanations about internal features and the identification of cooperation dynamics with the goal of creating and consolidating innovation networks.

The present article is focused in the cooperation determinants of innovation networks. It is particularly important to understand how innovation relates with different patterns of collaborative activities regarding knowledge production, exchange and transfer. In parallel, the study is interested in understanding the different behaviors of innovation actors and their likelihood to engage innovation. Using a novel approach, that mixes the selection of qualitative data based in content analysis of organizational websites with standard econometric tools, the study defines types of knowledge cooperation and links these with the specific actors' behavior and the emergence of innovation networks. For these goals, the article is organized as follows. A first section reviews evolutionary and institutional perspectives on innovation networks, clearly separating this notion from other interconnected, knowledge network.A second section presents methodological notes about the empirical analysis and the main interrogations that this study is trying to address. A third section presents an econometric exercise that provides insights for the determinants of innovation networks. The article concludes with policy implications.

\section{From knowledge flows to innovation networks}

\section{Innovation systems as the context for networks}

An innovation system is a set of actors that interact with the aim of creation and diffusion of knowledge, involving a number of different agents promoting new knowledge and its economically useful application. The commitment between actors may be or not formal, as different types of interactions occur within the innovation system (Edquist and Hommen, 1999; Capello, 2009b). Essentially, there is a focus on cooperation to foster knowledge flows. It is assumed that the greater the interaction, commitment and cooperation between the actors involved, the larger the innovation promoted within the system. The innovation system is based on the possibility that flows do not follow a route defined a priori. This is only possible by assuming that knowledge derives not only from scientific knowledge but also from the combination of different synthetic, analytical and symbolic forms of knowledge (Cooke and Leydesdorff, 2006; Asheim, 2007).
Innovation system approach can focus different scales and perspectives, from National Systems of Innovation (Lundvall, 1992), Sectoral Innovation Systems (Malerba, 1999) to Regional Innovation Systems (Cooke, 1998; Cooke and Leydesdorff, 2006; Asheim, 2007). The National Innovation Systems (NIS) have their main contributions in Lundvall (1992), Freeman (1995) and Nelson (1993), whose basic argument is that innovation comes from a socially embedded process of learning which can only be understood if framed in the institutional architecture, historical context and culture of a particular nation-state. According to this view, the dynamics of innovation regards to the fact that all individuals belong to a nation, defined by common culture, language and ethics, obtained in a single geographical space under one central State authority. The concept of RIS is inspired by the concept of NIS and coincides in several dimensions with other territorial models of innovation such as clusters or industrial districts (Asheim, 2007). The similarities with the NIS are notorious in the sense that it also emphasizes that innovation dynamics depends on elements embedded in territory and society. However, the importance is given to the regional level rather than national. This focus is justified by the existence of cultural and institutional differences between regions, different types of interactions that are developed specifically within each region (Cooke, 1998). RIS combines a focus on regions with a systemic approach (Cooke and Leydesdorff, 2006). Moreover, regions would be more prone to the establishment of systemic relations between actors (Asheim, 2007), through the strengthening of relations of trust (Cooke, 1998) that exists at the regional level, given the geographical and cognitive closer relation.

Companies expand and enhance innovative performance by strengthening internal and external interaction. Impacts at the firm level reflect an increased awareness and capacity of individual knowledge, which in turn will lead to an improved ability of the firm to leverage the individual capabilities and increasing capacity to absorb knowledge at the aggregate level.Absorptive Capacity is the capacity to explore, evaluate and use external knowledge. This ability depends on prior knowledge that can be derived from the basic knowledge, as a common language, to the latest technological knowledge (Cohen and Levinthal, 1990).

Innovation is the result of an interaction between local actors, government and research institutions. These interactions enable companies to overcome internal needs through relationships established in the territory (Fratesi and Senn, 2009). This dynamic tends to be self-reinforcing, since the companies tend to seek external knowledge. As knowledge becomes more complex, the knowledge produced internally is no longer sufficient. 
Starting from a basic assumption that geographical proximity effectively promotes the exchange of tacit knowledge through face-to-face contact, there is nevertheless a broader perspective on how this dynamic develops. Tacit knowledge is essential for creating competitiveness through innovation, by its own intrinsic characteristics: it is hardly codified, takes extensive periods to be acquired, is obtained primarily through experience, is extremely expensive and sensitive to the social context (Maggioni and Uberti, 2008). Therefore, tacit knowledge is hardly imitable or transferable to other regions and may be a source of competitiveness. Consequently, geographical proximity is one of the key-enablers of the transfer of tacit knowledge. However, physical proximity is not sufficient to ensure knowledge flows are transformed in stabilized networks. It takes intrinsic aspects of the territory, connected with the social capital (Putman, 1995) referring to the characteristics of a given society that facilitate coordinated action and function as the glue facilitating cooperation and learning (Cappellin and Steiner, 2002). Social capital is a complex phenomenon that involves the relationship and value of a particular group of players that can be activated to produce benefits to those that possess it (Field, 2003). It relates directly to the notion of embeddedness (Granovetter, 1985), suggesting that the actors do not work outside a social context, but are not limited to fulfilling a pre-determined role in accordance with the socio-cultural categories that occupy in a particular moment. Even if the exact role of social capital as an antecedent of innovation remains unclear (Barrutia and Echebarria, 2010), it is crucial as impacts both the performance of businesses and regions (Cooke et al. 2005). Economic, social, cultural and historical fields have a certain social capital, which in turn defines the cognitive models and learning in each region in each moment. It is worth noting that social capital is a spatial phenomenon. The first reason relates to the spatial distribution of actors that possess social capital. But other reasons are also relevant. A dense network of relationships is easier to maintain with proximity. This is even more true for weak links that need to be consistently lubricated, and are seen as crucial to the innovative dynamics (Rutten et al., 20l0).

Furthermore, in the innovation system perspective the linear model is replaced by chain-linked versions (based in Kline and Rosenberg, 1986), admitting multiple interactions in many different ways, loopbacks and feedbacks among actors as an essential source of innovation and self-reinforcing processes (Edquist and Hommen, 1999). Innovation systems are not tangible or restricted, are internally "alive" and relate primarily with networks of complex relationships, which allow knowledge flows to reproduce continuously. For this continuity to occur, innovation systems have to be opened, linking with other systems of innovation (Bramanti and Fratesi, 2009; Bramanti and Riggi, 2009), giving relevance to the role of networks and connections of territorial actors with other external networks (Fratesi and Senn, 2009; Uyarra, 20I0). Each system has its own channels that enable and allow its existence. Relationships between actors, when being continually enhanced, promote the stabilization of networks (Chaminade and Edquist, 2006).

\section{The Emergence of innovation networks}

Networks may have different origins and be constructed in different ways. Knowledge sharing gives a special feature to the dynamics of innovation systems. Shared knowledge usually results in the increasing of the reservoir of knowledge, contrasting with other economic inputs and factors of production that seem to diminish when shared (Sveiby, 200I). This situation created a growing emphasis on networks as a fundamental strategy for competitiveness. In the words of Storper (1997), if mass production was the recommended strategy three decades ago, currently the best strategy is the participation in networks. Networks in the context of knowledge economy imply the need for two key elements: cooperation and intentionality (Visser, 2009). Cooperation involves necessarily not only companies but other actors such as universities, research institutes, laboratories, public agencies and government. Knowledge networks are strategic processes in the sense that they are intentional, selective and repetitive, albeit temporary, of knowledge exchange between innovation actors. Networks rely on how acquaintance linkages are mobilized (Morone and Tayor, 2012). Knowledge networks depend on the past success, accumulated experience that may help to innovate together and increases the similarity of knowledge stocks. Tensions exist between the facility of engaging with partners that share a relevant proportion of commonalities and partners with different and complementary knowledge. The ways that actors overcome these tensions result in the variety of network structures (Cowan, Jonard and Zimmermann, 2006). Innovation networks are evolving entities that depend in the tacitness of the knowledge base and the irreversibility of the system (Llerena and Ozman, 2013). The evolution of networks also depends on the relations between leaders and followers (Grebel, 20I2).

Three aspects derive from the ideas explained above: first the existence of knowledge networks is a prerequisite for the dynamics of innovation in a systemic approach. The second aspect involves the attribute of trust. Networks involve a certain stability of relationships, so there is a central role for trust among the agents involved. Trust is the basis of social capital and for the promotion of knowledge sharing as it allows the reduction of risk and uncertainty (Capello, 1999). Trust is so important in the dynamics of innovation that the breach of trust is fatal to the successful operation of systemic interaction (Cooke, 1998). The third aspect derives 
from the recognition that for one hand, innovation involving creation and transfer of knowledge is essential for economic competitiveness, on the other, it is assumed that new knowledge does not always necessarily lead to economic gains. This last point raises a question, how to ensure that knowledge flows effectively become economically useful?

The relationship between knowledge production and economic growth is not clear or obvious in evolutionary frameworks. More precisely, knowledge networks alone do not guarantee economic gains, as the generation of knowledge does not imply necessarily economic usefulness (Bramanti and Riggi, 2009). Knowledge generated must be channeled in specific ways for promoting its economic valorization, transforming invention into innovation that is new economically useful knowledge, often connected with new product development. It is necessary that knowledge networks evolve into innovation networks, which require intense and fluid knowledge flows (Camagni and Capello, 2009; Cooke, 1998). In sum, it is argued that innovation networks have three additional features beyond the cooperation and intentionality characteristics of knowledge networks (Nijkamp et al., 20l0):

- $\quad$ Endowned with intelligent agents in the sense that they have a purpose, not only to work, but with the ability and intention to search for learning in a broad sense, aimed at the continuous creation, assimilation, use and transfer of knowledge with a logical and useful purpose. Agents do not only receive knowledge passively but are creative, find new solutions, actively contributing to the increasing complexity of knowledge.

- $\quad$ Exchange relations of knowledge are intense. The idea of intensity refers not only to the amount of knowledge exchanged in time. The intensity is related to the proximity of interests and with the opening of mentality, towards an open exchange and spontaneous knowledge. There is a focus towards the quality of relations and a real commitment to knowledge sharing and interactive learning.

- Thirdly, innovation networks have a dynamic synergy. This aspect comes from the cognitive environment that involves innovation networks, ensures the strengthening of networks and the continuity of evolutionary dynamics of the innovation system. It fosters innovation and provides the economic purpose of the network.

Altogether, innovation networks originate robust innovation systems, having an internal renewal capacity, making flows complex, as they create and distribute knowledge (Smith, 2002). In the case of clusters, its essence is the concentration of similar businesses in the territory, where there are vertical and horizontal relationships, therefore networks of economic activity (Porter, 1998). In the innovation system perspective, the assumption of the existence of knowledge networks, whose evolutionary process in the region will lead to innovation networks. These will be equipped with intelligent actors, intense relationships and dynamic synergies that, as Cooke (1998) points out, are committed to interactive learning. Specialization is important but diversity and complementarities of related actors and sectors is critical to the creation of Jacobs' spillovers within the system. An innovation system is a framework that will encompass the internal innovation networks but also external connectedness. In short, it is very important to emphasize that networks have an essential role on the systemic approach. Innovation systems consist of relationships and networks are the channels that enable these relationships.

\section{Preliminary Aspects for the Empirical Analysis}

Having presented the interest in studying innovation networks, as they are central for innovative dynamics and to structure robust innovation systems, in the following empirical section we will develop a confirmatory study about the types of cooperation flows that are prominent in innovation networks using a mixed methods approach qualitative and quantitative data and techniques.

We depart from the notion that innovation networks to exist require the focus in the economic usefulness. This is the distinctive character of innovation when compared with invention. The analysis gives emphasis for new product development, one of the types of innovation (OECD, 2005) that more clearly relates to direct economic benefit.

The literature underlined that innovation networks are explained by different patterns of cooperation channels and agglomeration. This study provides evidence of the likelihood of innovation actors participating in innovation networks given the behavioral constraints and the different types of entity. To this purposes it was necessary to gather data that provided information about the type of actors in the system, their spatial location, and the innovation-related cooperation activities.

The data collection was performed with a careful observation and content analysis of 820 internet websites of innovation actors. The data collected refers to the Portuguese innovation system and reveals not only the actual activities developed but also the strategic options of communication. Details on the recent evolution of the Portuguese NIS can be found in Guerreiro and Pinto (20I2). The database collection and sample are specified in detail in Galindo et al. (201I). The clean database comprised 623 organizations: 18 governmental agencies, 297 private 
organizations, 70 associations, 20 technological parks and centers, 58 R\&D organizations, 48 entrepreneurship support entities, 12 technological schools, 80 universities and university interfaces, and 14 other entities.

The content analysis of the qualitative data on the websites facilitated the creation of 12 binary variables related with the cooperation flows (table I). Content analysis is a set of techniques to understand communication, using systematic procedures and objectives to describe the explicit and latent content of the message (Bardin 2006). The content analysis followed three phases. The first stage was the pre-analysis, with the organization of the collected data with the aim of making it operational, streamlining the initial ideas and main goal. The second phase was the exploration of the material, which consisted in the examination of the material with the definition of categories and identifying units of meaning and context within data. The third phase of the content analysis was the treatment of the results, inference and interpretation, with the condensation and the highlight of the relevant information to the overall analysis, culminating in inferential interpretations. This is a moment of intuition, reflective and critical analysis. Descriptive statistics for all variables are presented in annex.

\begin{tabular}{|l|l|l|}
\hline Variables & Explanation & Number of Is \\
\hline CENTRAL_CITY & $\begin{array}{l}\text { A dummy variable I if organization is located in the capital city } \\
\text { (Lisbon) }\end{array}$ & I8I \\
\hline FIRM & I if the actor is a firm & 297 \\
\hline UNIV & I if actor is a university or other public research organization & 128 \\
\hline ORI & I if specific orientation towards innovation & 262 \\
\hline COOP & I if promoting partnership and cooperation & 299 \\
\hline AET & I if using external technologies & 139 \\
\hline PRD & I if promoting R\&D & 139 \\
\hline MG & I if managing technology and knowledge & 242 \\
\hline PK & I if promoting scientific knowledge & 314 \\
\hline SP & I if studying productive processes & 147 \\
\hline SE & I if supporting entrepreneurship & $8 \mathrm{I}$ \\
\hline KT & I if transferring knowledge to external actors & 273 \\
\hline
\end{tabular}

Table I: Selected Explicative Variables 
This set of explicative variables facilitates the comprehension of the different aspects illustrated in Figure I:

- $\quad$ Even if all the cooperation channels are theoretically relevant some may be critical to innovation networks;

- The localization in the capital city' where agglomeration economies tend to be more intense may be of different relative importance for different types of innovation actors;
The types of actors that are more engaged in the creation of innovation networks through new product development - the firms are an almost obvious actor but other actors, such as universities and other public research organizations, are also engaged in this specific matter?

- Channels of cooperation activities that influence innovation networks vary regarding the type of innovation actor.

The correlation analysis (table 2 ) also shows some interesting

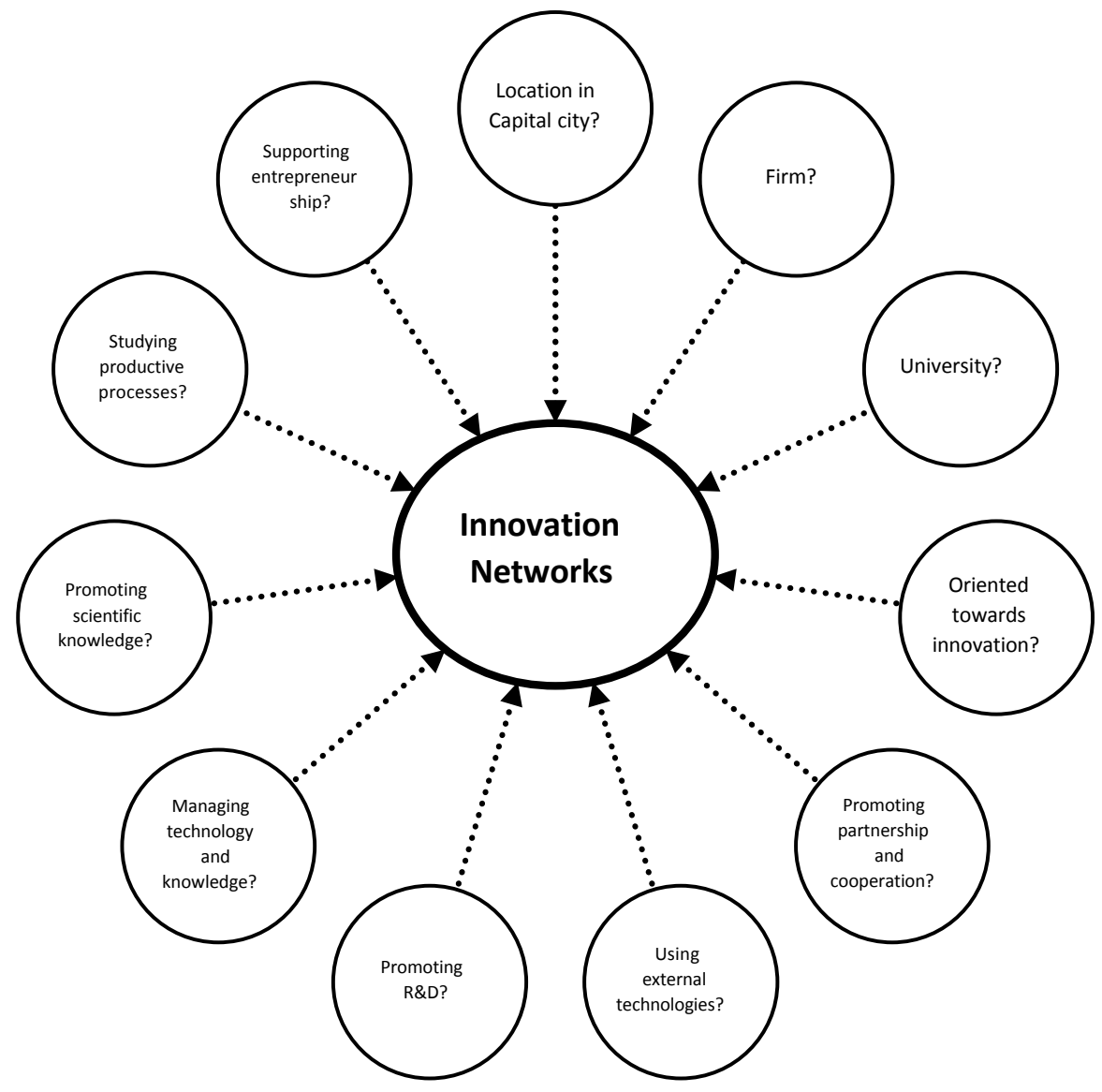

Figure I: Innovation Networks and Potential Determinants

\footnotetext{
'It is relevant to underline that Portugal is often seen as a centralized country. The European Regional Innovation Scoreboard 2012 is relevant to illustrate the relative discrepancies of Lisbon region to other Portuguese regions.
}

ISSN: 07 I8-2724. (http://www.jotmi.org) 
preliminary aspects. New product development (NPD) correlates positively with all the cooperation variables but more intensively with using external technologies (AET), promoting scientific knowledge (PK), and transferring knowledge to external actors (KT). Location in the central city is positively correlated with the presence of universities but negatively with the presence of firms, showing that the agglomeration of academic actors is more intense than the private ones. In general, cooperation activities are not correlated with this variable. The pattern of correlation between cooperation activities also shows that there are different degrees of association among these variables. There exist two groups of variables that seem more connected, on the one hand, external technologies (AET), orientation towards innovation (ORI), knowledge management activities (MG), and on the other hand, cooperation and partnership (COOP), studying processes (SP), supporting entrepreneurship (SE) and promotion R\&D (PRD). Activities for knowledge promotion (PK) and knowledge transfer (KT) seem to relate to both groups of variables.

\begin{tabular}{|c|c|c|c|c|c|c|c|c|c|c|c|c|c|}
\hline & $\begin{array}{c}\text { CENTRAL_- } \\
\text { CITY }\end{array}$ & AET & COOP & FIRM & ORI & NPD & PRD & MG & PK & SP & SE & $\mathrm{KT}$ & UNIV \\
\hline $\begin{array}{c}\text { CENTRAL_ } \\
\text { CITY }\end{array}$ & I & & & & & & & & & & & & \\
\hline AET & -0.035 & I & & & & & & & & & & & \\
\hline COOP & 0.115 & 0.402 & I & & & & & & & & & & \\
\hline FIRM & -0.214 & 0.336 & -0.244 & I & & & & & & & & & \\
\hline ORI & -0.009 & 0.501 & 0.681 & -0.102 & 1 & & & & & & & & \\
\hline NPD & 0.014 & 0.725 & $0.46 \mathrm{I}$ & 0.218 & 0.492 & 1 & & & & & & & \\
\hline PRD & 0.115 & 0.234 & 0.528 & -0.179 & 0.301 & 0.314 & I & & & & & & \\
\hline MG & 0.091 & 0.487 & 0.707 & -0.094 & 0.588 & 0.476 & 0.546 & I & & & & & \\
\hline PK & 0.091 & 0.453 & 0.773 & -0.161 & 0.743 & 0.529 & 0.464 & 0.668 & I & & & & \\
\hline SP & 0.079 & 0.398 & 0.410 & 0.050 & 0.373 & 0.467 & 0.513 & 0.437 & 0.535 & I & & & \\
\hline SE & -0.017 & 0.023 & 0.356 & -0.187 & 0.376 & 0.002 & 0.068 & 0.142 & 0.365 & 0.022 & I & & \\
\hline $\mathrm{KT}$ & 0.132 & 0.432 & 0.786 & -0.149 & 0.591 & 0.502 & 0.552 & 0.783 & 0.710 & $0.48 \mathrm{I}$ & 0.158 & 1 & \\
\hline UNIV & 0.173 & -0.176 & 0.149 & -0.485 & -0.112 & $-0.04 I$ & 0.376 & 0.238 & 0.044 & 0.140 & -0.067 & 0.207 & I \\
\hline
\end{tabular}

Table 2: Correlation

ISSN: 07 I8-2724. (http://www.jotmi.org) 


\section{Econometric results}

The econometric approach is inspired by a set of empirical contributions that focus the cooperation determinants on university-industry relations. Recent examples can be found in Gulbrandsen, Mowery and Feldman (20II) or Pinto and Esquinas (2013). A recent review of this type of analysis was presented in Perkmann et al. (20/3).

The dependent variable of this analysis, considered the proxy for the participation in innovation networks, is the new product development (NPD), connected with the economic usefulness of knowledge, that we directly associate with the existence of an innovation (table 3). The nature of this dependent variable, a binary variable, taking a value from $I$ or 0 , denoting the existence or absence of new product development, causes that a linear probability approach is inaccurate (Gujarati and Porter 2010). Since the NPD is binary, the error term in the estimated model will also be binary and follow a binomial distribution. The alternative method commonly used is a logistic regression with a maximum likelihood estimator, the LOGIT model. This method facilitates the understanding of the change in the probability of the occurrence of an event with the modification of the explanatory variables under evaluation.

\begin{tabular}{|l|l|l|l|l|}
\hline Value & Count & Percent & $\begin{array}{l}\text { Cumulative } \\
\text { Count }\end{array}$ & Percent \\
\hline 0 & 439 & 70.47 & 439 & 70.47 \\
\hline $\mathrm{I}$ & 184 & 29.53 & 623 & 100.00 \\
\hline
\end{tabular}

Table 3: Number of Zeros of Dependent Variable (NPD)
The estimation of a general model, including all sample cases underlines the relevance of several variables for new product development ${ }^{2}$. In annex, the complete tables for the different logistic regressions are presented. Linear probability models were also estimated for all regressions as confirmatory process of signals.

The general model shows that the most relevant cooperation channels for new product development are, in this order:

- $\quad \mathrm{AET}$ - using external technologies

- $\quad \mathrm{PK}$ - promoting scientific knowledge

- $\quad \mathrm{KT}-$ transferring knowledge to external actors

- ORI - specific orientation towards innovation

Entities that directly address managing technology and knowledge (MG) and the support of entrepreneurship (SE) have smaller probability to engage directly in innovation as both variables have negative signals. The other variables are not statistically significant. Additionally, being a firm is more relevant for the likelihood to new product development than being a university although both situations are positive and statistically significant. The location in the central city is not a critical factor for NPD.
${ }^{2}$ As there is no measure of goodness of fit in LOGIT, like R-squared is to OLS estimation (Dougherty 20I I), commonly used measures of the quality of the model are a pseudo R-squared (McFadden measure) or the predictive capacity (table in annex). These measures validate the quality of the estimated models.

ISSN: 07I 8-2724. (http://www.jotmi.org) 
Using the same principles, we estimated additionally three models for sub-samples. The goal was to understand the relative importance of the cooperation channels in the probability of generating innovation given the different types of entity. For the purpose it was created three groups of innovation actors, the first constituted by the 297 firms, the second groups of 128 universities and other public research organizations, and finally a third group of 198 other innovation actors. The results of these models are summarized in the table 4 .

\begin{tabular}{|l|l|l|l|l|}
\hline Variable & TOTAL SAMPLE & FIRMS & UNIVERSITIES & OTHERS \\
\hline C - Intercept & --- & --- & --- & --- \\
\hline Organization is located in the capital city & + & - & - & + \\
\hline AET - Using external technologies & ++++ & ++++ & ++++ & ++++ \\
\hline KT - Transferring knowledge & ++ & - & - & + \\
\hline MG - Managing technology and knowledge & -- & - & ++++ & $-\cdots$ \\
\hline ORI - Specific orientation towards innovation & +++ & ++ & + & +++ \\
\hline PK - Promoting scientific knowledge & ++++ & ++++ & + & - \\
\hline COOP - Promoting partnership and cooperation & + & + & + & + \\
\hline PRD - Promoting R\&D & + & - & - & + \\
\hline SE - Supporting entrepreneurship & --- & + & - & + \\
\hline SP - Studying productive processes & + & - & + & - \\
\hline
\end{tabular}

Table 4: Cooperation Determinants of Innovation

[Symbols: - non-significant negative coefficient; -- significant negative coefficient at 0.1 ; --- significant negative coefficient at 0.05 ; ---- significant negative coefficient at 0.01 ; + non-significant positive coefficient; ++ significant positive coefficient at 0.1 ; +++ significant positive coefficient at $0.05 ;++++$ significant positive coefficient at $0.0 \mathrm{l}]$. 
Firms are more likely to innovate with new product development if engaged in cooperation activities of promotion of knowledge (PK) and the utilization of external technologies (AET).Specific orientation for innovation (ORI) also has a relevant impact in the probability to innovate.

Regarding universities, the most relevant aspect is the proactive management of knowledge (MG). Universities and other public research organizations that are proactive in the management of their knowledge reservoir have a higher probability to develop new product developments. Other relevant channel for innovation is the utilization of external technologies (AET).

Other innovation actors are more willing to engage in innovation if they use external technologies (AET) or have a strategic focus to innovation (ORI). Nonetheless, the utilization of two types of cooperation flows are significant but negatively associated with the new product development. Most relevant is management of knowledge (MG). On the opposite situation of the universities, where MG was a critical positive aspect, when this group of actors gives emphasis to the management of knowledge are less likely to develop new products. On the same basis, innovation actors that are worried in the support to entrepreneurship (SE) are themselves less likely to introduce innovations by their own.

\section{Conclusive remarks}

The systemic approach brought new understandings to the innovation activities because these phenomena are transformed simultaneously into origins and consequences. Systems function as circuits for multiple reciprocal relationships where the complexity of the innovation dynamics will be unveiled. If on the one hand, linkages among actors create spillovers, the increase of cooperation and knowledge sharing generate more knowledge flows outside of firms leading to spillovers, on the other hand, the existence of spillovers leads to networks because increasingly the flow of external knowledge induces to an increased need for channels that enable shared and cooperative knowledge networks.

Assuming that in a given society social capital encourages interactive learning and knowledge flows, it tends to enhance the knowledge base by making it more complex. The complexity of the knowledge base and commitment to interactive learning, makes environment to embrace knowledge networks to answer to the need for proper channels of knowledge sharing. If there is an internal dynamics that favors the continuation of the process, knowledge flows become more intense having a qualitative effect on the interactions between actors. It creates linkages and growing trust in the creation, exchange and sharing of knowledge as well as an increasing involvement with learning. This is surrounded by a dynamic environment, where the growing complexity of knowledge requires a dynamic synergy between actors creating innovation networks.

Innovation networks arise from knowledge networks, which reached a level at which knowledge flows are intensively shared. Innovation networks are instigated from knowledge spillovers and the absorptive capacity of firms. Although there are several possible ways of how this dynamics may evolve, after the existence of innovation networks, there will be positive effects on economic performance. It is assumed that if innovation networks do not bring economic benefits, they cease to be useful, leading to its own degeneration and loss of internal dynamics. The economic aspect is part of the raison d'être of innovation networks and therefore the essence of innovation systems. Cooperative activities are connected with social capital, developing the preconditions for the dynamics of innovation occur.

Econometric results were illustrative of the relevance of particular types of cooperation activities for innovation networks exist. Firstly, it is important to underline that agglomeration benefits to new product development were not evident in the estimation, as the location of the innovation actors in the main city was not statistically significant in any model. In this way, the determinants of innovation were more related with specific cooperation activities. The utilization of external technologies is of greater relevance. This is indicative that much of innovation within knowledge networks can derive from absorbing external knowledge and incorporating new technologies in the productive processes. This means that this type of knowledge exchange channel should be taken seriously by policy-making and benefit from direct support for the improvement of the overall innovation system performance.

Other relevant feature regards the relevance of strategic orientation towards innovation. Actors that strategically orientate their activities are more likely to develop new products and thus creating innovation networks. This means that the qualification of strategic processes should also be targeted by policies that could improve the knowledge intelligence capacity.

Innovation actors are quite different in terms of what is determinant for them to innovate. It means that innovation policies that intend to develop networking and knowledge exchange need to address carefully the specificities of each type of actor. Besides the external linkages through technology acquisition, while for companies it is particularly relevant the active promotion of produced knowledge, universities need to develop the management of the 
existent knowledge reservoir. This implicates that firms should benefit from policies oriented to the promotion of the new knowledge produced in their networks, i.e., mainly an external feature, when, in parallel, universities need to benefit from policies for the upgrade of their internal knowledge management capabilities.

Another interesting result is that the engagement in particular types of activities that are crucial for the innovation, as supporting entrepreneurship, do not grant to these actors a status of innovator. In the fact is the contrary, supporters of innovation are relevant actors but not the innovators themselves. This clarification is extremely helpful for decision and policy makers, at different levels, from governments to university boards, that begin to confuse often the functions of innovation intermediation actors with the role of firms and research entities within innovation networks.

\section{Acknowledgments}

The authors are thankful to the financial support from FCT - Fundação para a Ciência e a Tenologia through INNOVAFLOW - Innovation Networks in Portugal: Flow Intensity, Knowledge Spillovers and Firm Performances (PTDC/CS-GEO/I0296I/2008). Hugo Pinto gratefully acknowledges the financial support from FCT (grant ref. SFRH/BPD/84038/2012). 


\section{References}

ASHEIM B (2007) Differentiated Knowledge Bases and Varieties of Regional Knowledge of Regional Innovation systems. The European J Soc. Science Res. 20: 223-24I. Doi: 10.1080/13511610701722846

BARDIN L (2006) Análise de conteúdo. Lisboa: Edições 70.

BARRUTIA J and ECHEBARRIA C (2010) Social capital, research and development, and innovation: An empirical analysis of Spanish and Italian regions. European Urban Regional Stud. 17: 371-385. doi: I0.1 I77/0969776409350689

BOSCHMA R (2005) Proximity and innovation. A critical assessment. Regional Stud. 39: 61-74. Doi: 10.1080/0034340052000320887

BRAMANTI A and FRATESI $U$ (2009) The Dynamics of an "Innovation Driven" Territorial Systems In Fratesi $U$ and SENN L (Ed.) Growth and Innovation of Competitive Regions - the Role of Internal and External Connections, Springer: Berlin, pp. 59-9l

BRAMANTI,A and RIGGI M (2009) Sustainable Interrelated Growth: A Phenomenal Approach In Fratesi $U$ and Senn L (Ed.) Growth and Innovation of Competitive Regions - the Role of Internal and External Connections, Springer: Berlin, Pp. 29-44

CAMAGNI R and CAPELLO R (2009). Knowledge -Based Economy and Knowledge Creation: The Role of Space In Fratesi $U$ and Senn L (Ed.) Growth and Innovation of Competitive Regions - the Role of Internal and External Connections, Springer: Berlin, pp. 145-165

CAPELLO R and NIJKAMP P (2009) Introduction: Regional Growth and Development Theories in Twenty First Century - Recent Theoretical Advances and Future Challenges In Capello R and Nijkamp P (Ed.) Handbook of Regional Growth and Development Theories, Edgar Elgar Publishing, Massachusetts, pp. I-I8

CAPELLO R (1999) Spatial Transfer of Knowledge in High Technology Milieu: Learning versus Collective Learning Process. Regional Stud. 33: 353-365. Doi: 10.1080/0034340995008I2I I

CAPELLO R (2009a) Spatial Spillovers and Regional Growth: a Cognitive Approach. European Plan. Stud., 17:640-658. Doi: 10.1080/09654310902778045
CAPELLO R (2009b) Space, Growth and Development. In Capello R and Nijkamp P (Ed.) Handbook of Regional Growth and Development Theories, Edgar Elgar Publishing, Massachusetts, pp. 33-52

CAPPELLIN, R and STEINER M (2002) Enlarging the Scale of Knowledge in Innovation Networks: Theoretical Perspectives and Policy Issues. Paper presented at the 42nd Congress of the European Regional Science Association (ERSA), Dortmund, Germany

CHAMINADE C and EDQUIST C (2006) From theory to practice: the use of systems of innovation approach in innovation policy, In Hage J and Meens M (Ed.) Innovation science and institutional change - Research Handbook, Oxford University Press, New York. pp. I4I-I62

COHENW and LEVINTHAL D (1990) Absorptive Capacity: a New Perspective on Learning and Innovation.Adm Science Q. 35: 128-152

COOKE P (1998) Introduction: Origins of the Concept In Braczyc H, Cooke P and Heideinrech M (Ed.), Regional Innovation Systems, UCL Press, London. Pp. 2-27

COOKE $P$ and LEYDESDORFF L (2006) Regional Development in the Knowledge-Based Economy: the Construction of Advantage. J. Tech Transf. 31: 5-15. Doi: I0.1007/s |096|-005-5009-3

COOKE P, Clifton N and Oleaga M (2005) Social Capital, Firm Embeddedness and Regional Development. Regional Stud. 39: I065-I077. Doi: I0.1080/00343400500328065

COOKE P and SCHIENSTOCK G (2000) Structural Competitiveness and Learning Regions. Enterp. Innovation Manag. Stud. I: 265-280. Doi: I0.1080/I46324400100232I7

DOUGHERTY C (201I) Introduction to Econometrics, Forth Edition, Oxford University Press, Oxford

EDQUIST C and HOMMEN L (1999) Systems of Innovation: Theory and Policy for the Demand Side.Tech Society 21:6379. Doi: 10.1016/S0160-791X(98)00037-2

FIELD J (2003) Social Capital, Routledge, London

FISCHER M (Ed) (2006) The New Economy and Networking In Fischer $M(E d)$ Innovations networks and knowledge spillovers. Springer,Viena. pp. 95-I I5 
FISCHER M and NIJKAMP P (2007) Entrepreneurship and Regional Development In Capello R and Nijkamp P (Ed.) Handbook of Regional Growth and Development Theories, Edward Elgar, Cheltenham. pp. 182-198

FISCHER M, Scherngell T and Jansenberger E (2009) Geographic Localisation of Knowledge Spillovers: Evidence from High-Tech Patent Citations in Europe. Annals Regional Science, 43: 839-858. Doi: 10.1007/s00 I68-009-0300-0

FLØYSAND A and JAKOBSEN S (2010) The complexity of innovation:A relational turn. Prog. Hum. Geography 35: 328344. Doi: 10.1 177/0309|325 I0376257

FRATESI U and SENN L (2009) Regional Growth Connections and Economic Modeling: an Introduction In Fratesi $U$ and Senn L (Ed.) Growth and Innovation of Competitive Regions - The Role of Internal and External Connections, Springer, Berlin. pp. 3-28

FREEMAN C (1995) The National System of Innovation in historical perspective. Cambridge Journal 19:5-24

FRENKEN K, Oort F and Verburg T (2007) Related Variety, Unrelated Variety and Regional Economic Growth, Regional Stud. 4I: 685-97. Doi: 10.1080/0034340060 I I 20296

GALINDO P, Vaz, T and Nijkamp P (20II) Institutional capacity to dynamically innovate: an application to the Portuguese case. Technol Forecast Soc Change 78: 3- I2. Doi: 10.1016/j.techfore.2010.08.004

GRANOVETTER M (1985) Economic action and social structure:The problem of embeddedness,Am.J.Soc. 91:48I510

GREBELT (2012) Network evolution in basic science.J Evol Econ. 2: 443-457. Doi: 10.1007/s00191-012-0266-4

GUERREIRO J and PINTO H (20I2) The engaged university and institutional changes in Portuguese innovation systems. Int. J. Transitions and Innovation Systems 2: 72-90. Doi: I0.1504/IJTIS.20I2.046937

GUJARATI D and PORTER D (2010) Essentials of Econometrics, Fourth Edition, Mcgraw-Hill, Singapore

GULBRANDSEN M, Mowery D and Feldman M (20ll) Introduction to the special section: Heterogeneity and university-industry relations. Res Policy 40: I-5
KIRAT T. and Lung $Y$ (1999) Innovation and Proximity: Territories as Loci of Collective Learning Process. European Urban and Regional Stud. 6: 27-38. Doi: 10.1177/096977649900600103

KLINE S and Rosenberg N (1986) An overview of innovation, In Landau $R$ and Rosenberg $N$ (Eds.) The Positive Sum Strategy: Harnessing Technology for Economic Growth. Washington, D.C.: National Academy Press. pp 275-305

LLERENA P and OZMAN M (2013) Networks, irreversibility and knowledge creation. J Evol Econ 23: 43I-453. Doi: I0.1007/s00|9|-0II-023I-7

LUNDVALL B (1992) National Systems of Innovation Toward a Theory of Innovation and Interactive Learning. Anthem Press, London

LUNDVALL B (1996) The Social Dimension of the Learning Economy. Danish Research Unit of Industrial Dynamics Druid Working paper, 96: I-20

MAGGIONI M and UBERTIT (2008) Knowledge Networks Across Europe: which Distance Matters? Annals of Regional Science 43: 69I-720. Doi: 10.1007/s00 I68-008-0254-7.

MALERBA F (1999) Sectoral Systems of Innovation and Production. Paper presented at the DRUID Conference on National Innovation Systems, Industrial Dynamics and Innovation Policy, Rebild, Denmark

MALERBA F (2006) Innovation and the evolution of industries. J Evol Econ 16: 3-23. Doi: 10.1007/s00191-0050005-I

MCCANN P and OORT F (2009). Theories of Agglomeration and Regional Economic Growth: a Historical Review In In CAPELLO R and NIJKAMP P (Ed.) Handbook of Regional Growth and Development Theories, Edgar Elgar Publishing, Massachusetts. pp. 19-32

MORONE P and TAYLOR R (2012) Proximity, knowledge integration and innovation: an agenda for agent-based studies. J Evol Econ 22: 19-47. Doi: 10.1007/s00 I9|-010-0200-6

NELSON R (ed.) (1993) National Systems of Innovation: a comparative studies, Oxford University Press, Oxford.

NELSON R and WINTER S (1982) An Evolutionary Theory of Economic Change. Press of Harvard University, Cambridge Massachusetts 
NIJKAMP P, Zwetsloot F and Wal S (2010) Innovation and Growth Potentials of European Regions: a MetaMulticriteria Analysis. European Plan. Stud. I8: 595-6I I. Doi: 10.1080/096543|10035935/5

NONAKA I (199I) The Knowledge-Creation Company, Harvard Business Review, 69: 96-104

NORTH D (199I) Institutions, J. Econ. Perspectives, 5: $97-$ 112

OCDE (2005) Oslo Manual - Guidelines for Collecting and interpreting innovation data. 3rd edition, OECD Publications, Paris.

PERKMANN M, Tartari V, McKelvey M, Autio E, Broström A, D'Este P, Fini R, Geuna A, Grimaldi R, Hughes A, Kitson M, Krabel S, Llerena P, Lissoni F, Salter A and Sobrero M (20I3) Academic Engagement and Commercialisation:A Review of the Literature on University-Industry Relations. Res Policy 42: 423-442. Doi: 10.10 I6/j.respol.20I2.09.007

PINTO $H$ and ESQUINAS M (20I3) Breadth, intensity and informality of university-industry interactions in a South European region: Exploring knowledge transfer dynamics in Andalusia In Baycan $T$ and Stough R (eds.) Knowledge Commercialization and Valorization in Regional Economic Development: New Perspectives and Challenges, Cheltenham, UK, Edward Elgar. pp. 209-237. DOI: I0.4337/978|781004074.000|8.

PORTER M (1998) Clusters and the New Economics of Competition, Harvard Business Review, 76: 77-90.

PUTMAN R (1995) Tuning In, Tuning Out: The Strange Disappearance of Social Capital in America. Pol. Science \& Politics 28: 664-683.

RODRÍGUEZ-POSE A and CRESCENZI R (2008) Research and Development, Spillovers, Innovation Systems, and the Genesis of Regional Growth in Europe, Regional Stud, 42: 5I-67. Doi: 10.1080/00343400701654|86.

RUTTEN R, Westlund $\mathrm{H}$ and Boekema $\mathrm{F}$ (2010) The spatial dimension of social capital, European Plan. Stud. 18:863-87I. Doi: I0.1080/096543 | 100370|38I.

SMITH K (2002) What is the "Knowledge Economy"? Knowledge Intensity and Distributed Knowledge Bases. UNU/INTECH - Discussion paper 2002(6), I-32.

STORPER M (1997) The Regional World, The Guilford Press, New York.
SVEIBY K (200I) A Knowledge-based Theory of the Firm to Guide Strategy Formulation.J. Intellect. Cap. 2: 344-358. Doi: 10.1108/1469193011040965I.

UYARRA E (2010) What is evolutionary about 'regional systems of innovation'? Implications for regional policy, J Evol Econ, 20: I I5-I37. Doi: 10.1007/s00 I II-009-0 I35-y.

UYARRA E and FLANAGAN K (2012) Reframing Regional Innovation Systems: evolution, complexity and public policy. In Cooke P (Ed.) Re-framing Regional Development, Routledge, Abingdon.

VISSER E (2009) The Complementary Dynamic Effects of Clusters and Networks. Ind. and Innovation 16: 167-195. doi: I0.1080//36627/0902764287. 


\section{Annex}

\begin{tabular}{|c|c|c|c|c|c|c|c|c|c|c|c|c|c|}
\hline & $\begin{array}{l}\text { CEN- } \\
\text { TRAL_ } \\
\text { CITY }\end{array}$ & AET & COOP & FIRM & ORI & NPD & PRD & MG & PK & SP & SE & $\mathrm{KT}$ & UNIV \\
\hline Mean & 0.291 & 0.222 & 0.479 & 0.476 & 0.421 & 0.294 & 0.223 & 0.389 & 0.503 & 0.235 & 0.130 & 0.439 & 0.206 \\
\hline Median & 0.000 & 0.000 & 0.000 & 0.000 & 0.000 & 0.000 & 0.000 & 0.000 & 1.000 & 0.000 & 0.000 & 0.000 & 0.000 \\
\hline Maximum & 1.000 & 1.000 & 1.000 & 1.000 & 1.000 & 1.000 & 1.000 & 1.000 & 1.000 & 1.000 & 1.000 & 1.000 & 1.000 \\
\hline Minimum & 0.000 & 0.000 & 0.000 & 0.000 & 0.000 & 0.000 & 0.000 & 0.000 & 0.000 & 0.000 & 0.000 & 0.000 & 0.000 \\
\hline Std, Dev, & 0.455 & 0.416 & 0.500 & 0.500 & 0.494 & 0.456 & 0.417 & 0.488 & 0.500 & 0.424 & 0.337 & 0.497 & 0.405 \\
\hline Skewness & 0.920 & 1.339 & 0.084 & 0.097 & 0.319 & 0.903 & 1.328 & 0.455 & -0.013 & 1.252 & 2.197 & 0.246 & 1.456 \\
\hline Kurtosis & 1.847 & 2.792 & 1.007 & 1.009 & 1.102 & 1.816 & 2.763 & 1.207 & 1.000 & 2.567 & 5.829 & 1.061 & 3.118 \\
\hline Jarque-Bera & 122.255 & 186.926 & 103.668 & 103.669 & 103.935 & 120.913 & 184.184 & 104.778 & 103.667 & 167.304 & 707.957 & 103.762 & 219.980 \\
\hline Probability & 0.000 & 0.000 & 0.000 & 0.000 & 0.000 & 0.000 & 0.000 & 0.000 & 0.000 & 0.000 & 0.000 & 0.000 & 0.000 \\
\hline Sum & 181.000 & 138.000 & 298.000 & 296.000 & 262.000 & 183.000 & 139.000 & 242.000 & 313.000 & 146.000 & 81.000 & 273.000 & 128.000 \\
\hline Sum Sq, Dev, & 128.330 & 107.383 & 155.228 & 155.138 & 151.640 & 129.159 & 107.937 & 147.846 & 155.494 & 111.730 & 70.452 & 153.178 & 101.659 \\
\hline
\end{tabular}

Table A I: Descriptive Statistics for Explanatory Variables (Total Sample)

\begin{tabular}{|c|c|c|c|c|c|c|c|}
\hline Variable & Mean & Variable & Standard Deviation & & & & \\
\hline & NPD $=0$ & NPD $=1$ & All & & NPD $=0$ & NPD $=1$ & All \\
\hline C & 1.000 & 1.000 & 1.000 & C & 0.000 & 0.000 & 0.000 \\
\hline CENTRAL_CITY & 0.287 & 0.298 & 0.291 & $\begin{array}{l}\text { CENTRAL_ } \\
\text { CITY }\end{array}$ & 0.452 & 0.459 & 0.454 \\
\hline FIRM & 0.405 & 0.646 & 0.477 & FIRM & 0.492 & 0.479 & 0.500 \\
\hline UNIV & 0.216 & 0.179 & 0.205 & UNIV & 0.412 & 0.385 & 0.404 \\
\hline ORI & 0.264 & 0.793 & 0.421 & ORI & $0.44 I$ & 0.406 & 0.494 \\
\hline COOP & 0.330 & 0.837 & 0.480 & COOP & 0.471 & 0.370 & 0.500 \\
\hline AET & 0.027 & 0.690 & 0.223 & AET & 0.163 & 0.464 & 0.417 \\
\hline PRD & 0.139 & 0.424 & 0.223 & PRD & 0.346 & 0.496 & 0.417 \\
\hline MG & 0.239 & 0.745 & 0.388 & MG & 0.427 & 0.437 & 0.488 \\
\hline PK & 0.332 & 0.913 & 0.504 & PK & 0.472 & 0.283 & 0.500 \\
\hline SP & 0.107 & 0.543 & 0.236 & SP & 0.310 & 0.499 & 0.425 \\
\hline SE & 0.130 & 0.130 & 0.130 & SE & 0.336 & 0.338 & 0.337 \\
\hline KT & 0.278 & 0.821 & 0.438 & KT & 0.448 & 0.385 & 0.497 \\
\hline Observations & 439 & 184 & 623 & Observations & 439 & 184 & 623 \\
\hline
\end{tabular}

Table A2: Descriptive statistics for Explanatory Variables (taking into consideration NPD)

ISSN: 07I 8-2724. (http://www.jotmi.org)

Journal of Technology Management \& Innovation (C) Universidad Alberto Hurtado, Facultad de Economía y Negocios. 


\begin{tabular}{|c|c|c|c|c|}
\hline Variable & Coefficient & Std. Error & t-Statistic & Prob. \\
\hline $\mathrm{C}$ & -0.058 & 0.028 & -2.032 & 0.042 \\
\hline CENTRAL_CITY & 0.006 & 0.026 & 0.247 & 0.804 \\
\hline FIRM & 0.110 & 0.031 & 3.498 & 0.000 \\
\hline UNIV & 0.097 & 0.038 & 2.535 & 0.011 \\
\hline ORI & 0.070 & 0.039 & 1.760 & 0.078 \\
\hline COOP & 0.059 & 0.046 & 1.271 & 0.204 \\
\hline AET & 0.579 & 0.038 & 14.959 & 0.000 \\
\hline PRD & 0.002 & 0.038 & 0.070 & 0.944 \\
\hline MG & -0.108 & 0.042 & -2.545 & 0.011 \\
\hline PK & 0.177 & 0.045 & 3.889 & 0.000 \\
\hline SP & 0.084 & 0.036 & 2.332 & 0.020 \\
\hline SE & -0.145 & 0.040 & -3.622 & 0.000 \\
\hline KT & 0.099 & 0.045 & 2.181 & 0.029 \\
\hline R-squared & 0.613 & Mean dependent var & 0.295 & \\
\hline Adjusted R-squared & 0.606 & S.D. dependent var & 0.456 & \\
\hline S.E. of regression & 0.286 & Akaike info criterion & 0.358 & \\
\hline Sum squared resid & 50.065 & Schwarz criterion & 0.450 & \\
\hline Log likelihood & -98.643 & F-statistic & 80.810 & \\
\hline Durbin-Watson stat & 1.682 & Prob(F-statistic) & 0 & \\
\hline
\end{tabular}

Table A3: Linear Probability Model OLS for NPD (total sample $n=623$ ) 


\begin{tabular}{|c|c|c|c|c|}
\hline \multirow[b]{2}{*}{ Variable } & \multirow[b]{2}{*}{ Coefficient } & \multirow[b]{2}{*}{ Std. Error } & \multicolumn{2}{|c|}{$\begin{array}{r}\text { Dependent Variable: NPD } \\
\text { Method: ML - Binary Logit (Quadratic hill climbing } \\
\text { Included observations: } 623 \\
\text { Convergence achieved after } 6 \text { iterations } \\
\text { Covariance matrix computed using second derivatives }\end{array}$} \\
\hline & & & z-Statistic & Prob. \\
\hline C & -4.991 & 0.526 & -9.482 & 0.000 \\
\hline CENTRAL_CITY & 0.0823 & 0.313 & 0.262 & 0.792 \\
\hline FIRM & 1.710 & 0.448 & 3.816 & 0.000 \\
\hline UNIV & 1.247 & 0.482 & 2.587 & 0.009 \\
\hline ORI & 0.835 & 0.385 & 2.165 & 0.030 \\
\hline COOP & 0.870 & 0.537 & 1.619 & 0.105 \\
\hline AET & 3.166 & 0.412 & 7.676 & 1.630 \\
\hline PRD & 0.007 & 0.409 & 0.018 & 0.985 \\
\hline MG & -1.006 & 0.438 & -2.296 & 0.021 \\
\hline PK & 1.874 & 0.480 & 3.9046 & 0.000 \\
\hline SP & 0.383 & 0.354 & 1.079 & 0.280 \\
\hline SE & -1.157 & 0.434 & -2.665 & 0.007 \\
\hline KT & 0.890 & 0.484 & 1.838 & 0.066 \\
\hline Mean dependent var & 0.295 & S.D. dependent var & 0.456 & \\
\hline S.E. of regression & 0.282 & Akaike info criterion & 0.568 & \\
\hline Sum squared resid & 48.676 & Schwarz criterion & 0.661 & \\
\hline Log likelihood & -164.080 & Hannan-Quinn criter. & 0.604 & \\
\hline Restr. log likelihood & -378.079 & Avg. log likelihood & -0.263 & \\
\hline LR statistic (12 df) & 427.996 & McFadden R-squared & 0.566 & \\
\hline Probability(LR stat) & 0 & & & \\
\hline Obs with Dep $=0$ & 439 & Total obs & 623 & \\
\hline Obs with Dep=I & 184 & & & \\
\hline
\end{tabular}

Table A4: Logistic regression (total sample)

The model with the substituted coefficients is presented below:

NPD=I-@LOGIT[-(-4.99+0.082*CENTRAL_CITY+I.7I $0 * F I R M+I .247 * U N I V+0.87$ I*COOP+3.166*AET

$+0.836 * \mathrm{ORI}+0.008 * \mathrm{PRD}-\mathrm{I} .006 * \mathrm{MG}+\mathrm{I} .874 * \mathrm{PK}+0.383 * \mathrm{SP}-\mathrm{I} .158 * \mathrm{SE}+0.89 \mathrm{I} * \mathrm{KT})]$

ISSN: 07 I8-2724. (http://www.jotmi.org)

Journal of Technology Management \& Innovation (C) Universidad Alberto Hurtado, Facultad de Economía y Negocios. 


\begin{tabular}{|c|c|c|c|c|c|c|}
\hline \multicolumn{7}{|l|}{ Prediction Evaluation (success cutoff $C=0.5$ ) } \\
\hline & $\begin{array}{l}\text { Estimated } \\
\text { Equation }\end{array}$ & $\begin{array}{l}\text { Constant } \\
\text { Probability }\end{array}$ & & & & \\
\hline & Dep $=0$ & Dep $=I$ & Total & Dep $=0$ & Dep $=I$ & Total \\
\hline$P($ Dep $=I)<=C$ & 413 & 48 & 461 & 439 & 184 & 623 \\
\hline$P($ Dep $=I)>C$ & 26 & 136 & 162 & 0 & 0 & 0 \\
\hline Total & 439 & 184 & 623 & 439 & 184 & 623 \\
\hline Correct & 413 & 136 & 549 & 439 & 0 & 439 \\
\hline$\%$ Correct & 94.077 & 73.913 & 88.121 & 100 & 0 & 70.465 \\
\hline$\%$ Incorrect & 5.923 & 26.087 & 11.879 & 0 & 100 & 29.535 \\
\hline Total Gain* & -5.922 & 73.913 & 17.656 & & & \\
\hline \multirow[t]{3}{*}{ Percent Gain** } & & 73.913 & 59.782 & & & \\
\hline & $\begin{array}{l}\text { Estimated } \\
\text { Equation }\end{array}$ & $\begin{array}{l}\text { Constant } \\
\text { Probability }\end{array}$ & & & & \\
\hline & Dep $=0$ & Dep $=I$ & Total & Dep $=0$ & Dep $=I$ & Total \\
\hline$E(\#$ of $D e p=0)$ & 390.498 & 48.501 & 438.999 & 309.343 & 129.656 & 439 \\
\hline$E(\#$ of $D e p=I)$ & 48.501 & 135.498 & 184.000 & 129.656 & 54.343 & 184 \\
\hline Total & 439 & 184 & 623 & 439 & 184 & 623 \\
\hline Correct & 390.498 & 135.498 & 525.997 & 309.343 & 54.343 & 363.686 \\
\hline$\%$ Correct & 88.952 & $73.64 I$ & 84.430 & 70.465 & 29.535 & 58.377 \\
\hline$\%$ Incorrect & 11.048 & 26.359 & 15.570 & 29.534 & 70.465 & 41.623 \\
\hline Total Gain* & 18.486 & 44.106 & 26.053 & & & \\
\hline Percent Gain** & 62.592 & 62.592 & 62.592 & & & \\
\hline \multicolumn{7}{|c|}{$\begin{array}{l}\text { *Change in "\% Correct" from default (constant probability) } \\
\text { specification }\end{array}$} \\
\hline $\begin{array}{l}\text { **Percent of incorrect (default) prediction cor } \\
\text { tion }\end{array}$ & & & & & & \\
\hline
\end{tabular}

*Change in "\% Correct" from default (constant probability) specification

**Percent of incorrect (default) prediction corrected by equation Table A5: Predictive capacity of the LOGIT model for NPD 
Dependent Variable: NPD

Method: ML - Binary Logit (Quadratic hill climbing)

Convergence achieved after 6 iterations

Covariance matrix computed using second derivatives

\begin{tabular}{|l|l|l|l|}
\hline Variable & Coefficients FIRMS & Coefficients UNIVERSITIES & Coefficients OTHERS \\
\hline C & $-4.095^{* * *}$ & $-41.752^{* * *}$ & $-3.880^{* * *}$ \\
\hline AET & $2.58 I^{* * *}$ & $3.10 I^{* * *}$ & $3.185^{* * *}$ \\
\hline CENTRAL_CITY & -0.410 & -0.986 & 0.632 \\
\hline KT & -0.823 & -0.970 & 1.579 \\
\hline MG & -0.488 & $42.249 * * *$ & $-2.825^{* * *}$ \\
\hline ORI & $1.918^{*}$ & 0.0757 & $2.332^{* *}$ \\
\hline PK & $3.087^{* * *}$ & 0.0887 & -0.776 \\
\hline COOP & 1.069 & 0.892 & 1.237 \\
\hline PRD & -0.129 & -1.316 & 1.247 \\
\hline SE & 0.713 & -0.684 & $-2.450^{* *}$ \\
\hline SP & 1.292 & 0.796 & -1.128 \\
\hline McFadden R-squared & 0.798 & 0.395 & 0.437 \\
\hline Obs with Dep=0 & 178 & 95 & 166 \\
\hline Obs with Dep=I & 119 & 33 & 32 \\
\hline Total Observations & 297 & 128 & 198 \\
\hline
\end{tabular}

***significant at $0.01, * *$ significant at 0.05 ; *significant at 0.1 .

Table A6: Model for Firms, Universities and Other Actors 